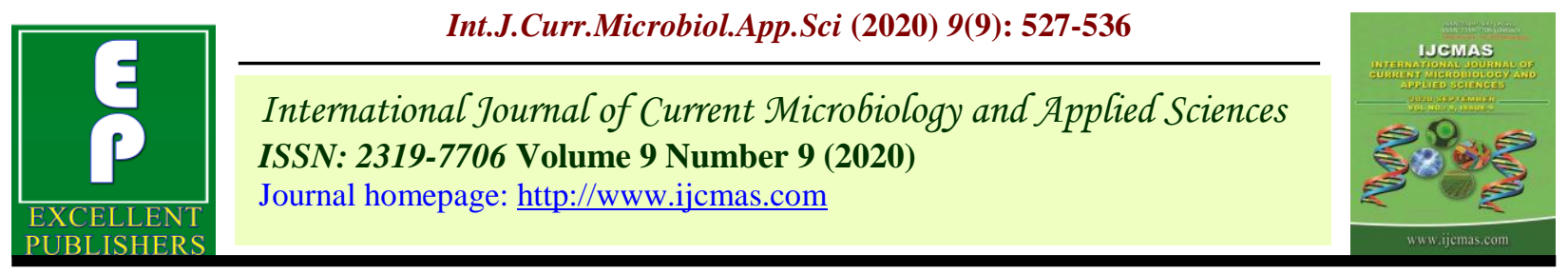

Original Research Article

https://doi.org/10.20546/ijcmas.2020.909.067

\title{
Impact of Long Term Fertilization on Soil Properties and Soybean Productivity in a Vertisol
}

\author{
Jalendra Bairwa*, B. S. Dwivedi, A. K. Dwivedi, R. K. Thakur and N. Patidar \\ Department of Soil Science and Agricultural Chemistry, Jawaharlal Nehru Krishi Vishwa \\ Vidyalaya, Jabalpur, Madhya Pradesh, India 482004 \\ *Corresponding author
}

\begin{abstract}
A B S T R A C T
\section{Keywords}

Soybean yield,

FYM, LTFE,

Organic Carbon,

Vertisols

Article Info

Accepted:

07 August 2020

Available Online:

10 September 2020

The present investigation was conducted during 2018-19 under All India Coordinated Research Project on "Long Term Fertilizer Experiment" at the Research Farm Department of Soil Science and Agricultural Chemistry, Jawaharlal Nehru Krishi Vishwa Vidyalaya, Jabalpur (M.P.), which was commenced since 1972, to assess the effect of continuous application of different fertilizer with or without organic manure on soil fertility and soybean productivity. There was ten treatments i.e. $\mathrm{T}_{1}(50 \% \mathrm{NPK}), \mathrm{T}_{2}(100 \% \mathrm{NPK}), \mathrm{T}_{3}$ $(150 \% \mathrm{NPK}), \mathrm{T}_{4}(100 \% \mathrm{NPK}+$ Hand weeding $), \mathrm{T}_{5}(100 \% \mathrm{NPK}+\mathrm{Zn}), \mathrm{T}_{6}(100 \% \mathrm{NP}), \mathrm{T}_{7}$ $(100 \% \mathrm{~N}), \mathrm{T}_{8}(100 \% \mathrm{NPK}+5$ t FYM ha- 1$), \mathrm{T}_{9}(100 \% \mathrm{NPK}-\mathrm{S})$ and $\mathrm{T}_{10}$ (Control), which replicated four times in a randomized block design. The findings of the present investigation revealed that the application of recommended dose of N, P and K (20:80:20 $\mathrm{kg}$ ha-1) with organic manure (@ 5 FYM ha-1) enhanced soybean crop yields over control plot. Further, the integrated use of FYM with $100 \%$ NPK substantially improved the organic carbon content by $2.9 \mathrm{~g} \mathrm{~kg}-1$ as well as available $\mathrm{N}$ and $\mathrm{P}$ in soil over its initial values, thereby indicating significant contribution towards sustaining the soil health. Thus, the balance use of fertilizers continuously either alone or in combination with organic manure is necessary for sustaining soil fertility and soybean productivity.
\end{abstract}

\section{Introduction}

Soybean [Glycine $\max$ (L.) Merri.] an important protein as well as oil seed crop belonging to leguminosae family that is for its nutritional value, called and considered as "Protein hope of future". Generally, soybean contains $40-45 \%$ protein while content of seed oil contributes to about 18-20\% (Ibrahim and Kandil, 2007). Soybean is one of the major global crops that also have a unique role in sustainable agriculture due to its ability to fix atmospheric nitrogen through symbiotic interactions with rhizobia in the soil (Keyser and $\mathrm{Li}, 1992$ ). The area of soybean in the world is about $129.30 \mathrm{~m}$ ha and yield of soybean in the world is about $370.50 \mathrm{~m} \mathrm{t}$ in 2018. In India, soybean is grown in about $10.96 \mathrm{M}$ ha under diverse agro-climatic and soil conditions with average production and productivity of 13.45 million tonnes and 1.22 $\mathrm{t}$ ha-1, respectively (Directorate of Economics 
and Statistics, 2018). While in Madhya Pradesh it is cultivated in an area of 54.01 Lakh ha with productivity of $1.23 \mathrm{t}$ ha- 1 and contributes about $60 \%$ production from around $55 \%$ of soybean grown area of the country (Ministry of Agriculture GOI, 2016). The low productivity in the state and country calls for optimizing it through efficient nutrient management. The lack of integrated nutrient management approach coupled with unbalanced nutrition not only limits the productivity, but also leads to deterioration in soil quality (Sharma et al., 2016). Long term fertilizer experiments can be used for precise monitoring of changes in soil fertility and productivity. This helps in solving the complex problems related to soil fertility management. There is an apprehension that the use of chemical fertilizers over the years may impair soil fertility. In continuous cropping, use of imbalance nutrients ( $\mathrm{N}$ or $\mathrm{NP}$ alone) through inorganic fertilizers without organic manure cannot sustain the desired level of crop production (Thakur et al., 2009). Integration of inorganic fertilizers with organic manures will not only sustain crop production but also be effective in improving soil health and enhancing the nutrient use efficiency (Thakur et al., 2011). An adequate information is lacking on the effect of continuous cropping and fertilization on soil properties and crop productivity in a Vertisol, hence the present study was undertaken.

\section{Materials and Methods}

The Long Term Fertilizer Experiment initiated at the Research farm of the Department of Soil Science and Agricultural Chemistry, Jawaharlal Nehru Krishi Vishwa Vidyalaya Jabalpur since 1972. This experiment was focused to study changes in number of nodules, nitrogen fixation and yield of soybean by the continuous application of different dose of fertilizer and manure. In this regard, an investigation was carried out during Kharif season 2018-19. It is situated at $23^{\circ} 10^{\prime} \mathrm{N}$ latitude and $79^{\circ} 57^{\prime \prime} \mathrm{E}$ longitude at 393 meters above the mean sea level. The temperature during this period varies from 25 to $35^{\circ} \mathrm{C}$ and the relative humidity ranges between 70 to 80 per cent. The average annual rainfall varies from 1200 to $1500 \mathrm{~mm}$. The soil of the experimental field is medium black $(56.82 \%$ clay $)$ belonging to Kheri series of fine montmorillonitic hyperthermic family of Typic Haplustert and had $\mathrm{pH}$ of 7.6, electrical conductivity $0.18 \mathrm{dS} \mathrm{m}-1$ (1: 2.5 soil: water ratio) and organic carbon $5.7 \mathrm{~g} \mathrm{~kg}-1$. The soil available $\mathrm{N}, \mathrm{P}, \mathrm{K}$ and $\mathrm{S}$ were 193, 7.6, 370 and $15.6 \mathrm{~kg}$ ha- 1 , respectively. Also, at the start of the experiment, the concentrations of soil available $\mathrm{Zn}, \mathrm{Fe}, \mathrm{Mn}$ and $\mathrm{Cu}$, in the surface soil were $0.33,2.47,16.10$ and 0.11 mg kg-1 soil, respectively. The experiment included 10 treatments viz., $\mathrm{T}_{1}-50 \% \mathrm{NPK}$, $\mathrm{T}_{2}-100 \% \mathrm{NPK}, \mathrm{T}_{3}-150 \% \mathrm{NPK}, \mathrm{T}_{4}-100 \%$ $\mathrm{NPK}+$ Hand weeding, $\mathrm{T}_{5}-100 \% \mathrm{NPK}+\mathrm{Zn}$, $\mathrm{T}_{6}-100 \% \mathrm{NP}, \mathrm{T}_{7}-100 \% \mathrm{~N}, \mathrm{~T}_{8}-100 \% \mathrm{NPK}$ +15 t FYM ha-1, $\mathrm{T}_{9}-100 \%$ NPK $-\mathrm{S}$ (Sulphur free) and $T_{10}$ - Control, each replicated four times in a randomized block design. The gross plot size being 17 x $10.8 \mathrm{~m}$ with $1 \mathrm{~m}$ spacing between the plots and $2 \mathrm{~m}$ spacing between the replications.

The recommended $\mathrm{N}, \mathrm{P}$ and $\mathrm{K}$ dose for soybean, based on initial soil test, was $20 \mathrm{~kg}$ $\mathrm{N}, 80 \mathrm{~kg} \mathrm{P}_{2} \mathrm{O}_{5}$ and $20 \mathrm{~kg} \mathrm{~K}_{2} \mathrm{O}$ ha- 1 . The sources of $\mathrm{N}, \mathrm{P}$ and $\mathrm{K}$ used were urea, single super phosphate and muriate of potash. In sulphur free treatment, diammonium phosphate (DAP) was used instead of SSP as source of P. Zinc application @ of $20 \mathrm{~kg}$ $\mathrm{ZnSO}_{4}$ ha-1 in alternate years to wheat crop was followed till 1987. Due to high build-up of $\mathrm{Zn}$, its addition is discontinued till date. The application of FYM @ 5 t ha-1 year-1 was applied only to soybean crop during kharif season. $100 \%$ NPK $+\mathrm{HW}$ treatment weeding is done manually, whereas in other 
treatments chemical weed control (herbicide) was followed.

For the present investigation soil samples were drawn from surface $0-20 \mathrm{~cm}$ soil depths in the 46th cropping year (2018-19) and were analysed for different parameters by following standard procedures for soil $\mathrm{pH}$ was determined in a 1:2.5 soil water suspension by glass electrode $\mathrm{pH}$ meter (Piper, 1950). Electrical conductivity was determined by using conductivity meter (Piper, 1950), organic carbon (Walkley and Black 1934), available N (Subbiah and Asija 1956), available $\mathrm{P}$ (Olsen et al., 1954) and available K ((Muhr et al., 1965). Determination of Calcium Carbonate was done by Rapid titration method as described by Puri (1930). For the calculation of soybean grain and straw yields in each plot $5 \times 4 \mathrm{~m} 2$ was harvested. After complete air drying, the bundles were weighed and data recorded. The produce was threshed and a grain and straw yields of soybean were recorded. The grain and straw of soybean was taken to determine nutritional consistence. For the determination of nitrogen content in soybean crop micro kjeldahl method (AOAC, 1965), for phosphorus content of the plant extract was determined using Vanado Molybdo phosphoric yellow colour method (Bhargava \& Raghupathi, 1984) and potassium was determined with the help of flame photometer (Bhargava \& Raghupathi, 1984). On the basis on nutrient content the nutrient uptake of soybean was calculated in kg ha- 1 in relation to (dry matter production) yield ha-1. All observations recorded on soybean yield, nutrients uptake and soil properties were analysed statistically.

\section{Results and Discussion}

\section{Basic Soil Properties (pH, EC, Organic carbon and Calcium carbonate)}

There were no significant differences could be noticed with soil reaction $(\mathrm{pH})$ due to different treatment of fertilizers and manure (Table 1). The soil $\mathrm{pH}$ did not significantly show any visible trend in all the treatment after harvest of the crop. The highest $\mathrm{pH}$ value 7.59 was recorded in control and lowest value 7.45 in $100 \% \mathrm{~N}$ alone and $100 \% \mathrm{NPK}+$ FYM treatment. This could be due to the high buffering capacity of the soil and presence of appreciable content of free calcium carbonate (Divya et al., 2016). Similarly soil EC value was also found to be no changed over initial which ranged between 0.14 and $0.18 \mathrm{dSm}-1$. It was found that imposition of various doses of fertilizers and manure did not affect significantly to electrical conductivity of soil in a Vertisol (Thakur et al., 2009). The continuous use of inorganic fertilizers over a long period of time had no marked influence on EC of the soil and conjoint use of FYM and fertilizer might cause meager change which could be due to addition of organic manure which increased the buffering capacity of the soil reported by Dwivedi and Dwivedi (2015).

The organic carbon content significantly increased with increasing levels of fertilizer application (Table 1). The lowest value was noted in control (4.70 $\left.\mathrm{g} \mathrm{kg}^{-1}\right)$ which was increased to $6.21,7.22$ and $8.03 \mathrm{~g} \mathrm{~kg}-1$ due to application of recommended dose of $50 \%$ NPK, $100 \%$ NPK, and $150 \%$ NPK respectively. However, the highest value (8.61 g kg-1) was recorded with $100 \%$ NPK+FYM treatment. The super optimal dose showed a significantly higher content of organic carbon over sub optimal dose optimal dose. The value of $\mathrm{OC}$ was found to be slightly changed at harvest of crop. The OC value was increased to $6.22,7.24$ and $8.03 \mathrm{~g}$ $\mathrm{kg}-1$ due to application of $50 \%$ NPK, $100 \%$ NPK, and $150 \%$ NPK dose of fertilizers respectively. The lowest value was recorded in control (4.68 $\mathrm{g} \mathrm{kg}-1)$ and the highest value (8.63 g kg-1) was recorded with $100 \%$ $\mathrm{NPK}+\mathrm{FYM}$ treatment. continuous application 
of FYM alone or in combination with inorganic fertilizer results in higher organic carbon content as compared to in inorganic fertilizer application after harvest of soybean was reported by (Patel et al., 2018 and Mundhe et al., 2018).

The data on calcium carbonate content in soils are presented in Table 1, indicated the highest value was recorded in $150 \%$ NPK (50.9 g $\mathrm{kg}^{-1}$ ) and the lowest value was recorded in control (39.3 $\left.\mathrm{g} \mathrm{kg}^{-1}\right)$. With the increase in doses of application of fertilizers the value of calcium carbonate was increased as $50 \%$ NPK, $100 \%$ NPK and 150\% NPK (43.7, 46.0 and $50.9 \mathrm{~g} \mathrm{~kg}^{-1}$ ) respectively. Higher value of $\mathrm{CaCO}_{3}$ in soil after harvest of soybean and wheat crops was recorded in the treatments of balanced application of nutrients and lower values in imbalanced nutrient application treatments. It may be due to long term application of SSP which also contains calcium (Nagwanshi et al., 2018).

\section{Available Nitrogen}

The data pertaining to soil available $\mathrm{N}$ was significantly highest in optimal dose of fertilizer with FYM (351 $\mathrm{kg} \mathrm{ha}^{-1}$ ) and the lowest available $\mathrm{N}$ content was found in control plot. These results are in line with findings of Khamparia et al., (2018) who observed that available nitrogen content in soil increased significantly with the use of recommended dose of fertilizer in combination with manure. Further, by increasing the application rate of nutrients, the amount of available nutrients also increased significantly $\left(\mathrm{T}_{8}\right.$ and $\left.\mathrm{T}_{3}\right)$.

However, application of phosphorus along with nitrogen (100\% NP) improved the available nitrogen status of the soil in comparison to the application of nitrogen alone $(100 \% \mathrm{~N})$, and further the application of potassium with $100 \%$ NP (100\% NPK) had also improved $\mathrm{N}$ content (295 kg ha-1) in soil. Sharma et al., (2015) also reported an increase in available nitrogen contents due to graded application of NPK. Control plot showed reduction in the available nitrogen status due to removal of nutrients with continuous cropping without fertilization (Raghuwanshi et al., 2016). Shirale et al., (2014) reported that the higher gain of available $\mathrm{N}$ was found only in FYM treated plots as compared to $100 \%$ NPK treatment.

\section{Available Phosphorous}

The data on available $\mathrm{P}$ was presented in Table 1 found that imbalanced use of fertilizers reduced the available $P$ content in the soil. A significant reduction in available $\mathrm{P}$ content observed under nitrogen alone $(100 \%$ $\mathrm{N})$ and unfertilized treatments occurred due to removal of $\mathrm{P}$ by the crops in the absence of $\mathrm{P}$ supplementation through external source. Use of $100 \% \mathrm{NP}$ over $100 \% \mathrm{~N}$ significantly increased the available $\mathrm{P}$ status of soil. Similar trend on available $\mathrm{P}$ was reported by Khamparia et al., (2018). Further, the application of $100 \%$ NPK over $100 \%$ NP had no significant effect on available $\mathrm{P}$ status. A marked build-up of available P status of soil was observed under $100 \%$ NPK + FYM and $150 \%$ NPK treatments (Thakur et al., 2009).

\section{Available Potassium}

The data of available $\mathrm{K}$ indicated a declining trend (238 to $333 \mathrm{~kg}$ ha-1) from its initial level $(370 \mathrm{~kg}$ ha-1) which indicates considerable mining of available soil $\mathrm{K}$ after 46 years of soybean - wheat intensive cropping (Table 1).

The maximum decline was observed in case of control followed by $100 \% \mathrm{~N}$ alone; the magnitude of decline decreased with increasing levels of NPK application. Among the inorganic fertilizers, continuous 
application of N or NP had depressive effect on available $\mathrm{K}$ content of the soil which may be due to nutrient imbalance in the soil. Continuous omission of $\mathrm{K}$ in crop nutrition caused mining of its native pools that caused reduction in the crop yields (Thakur et al., 2011 and Sawarkar et al., 2013). However, the highest available $\mathrm{K}$ status of soil found associated with $100 \%$ NPK+FYM followed by $150 \%$ NPK treatments. The application of organic manure may have caused reduction in $\mathrm{K}$ fixation and consequentially increased $\mathrm{K}$ content due to interaction of organic matter with clay besides the direct addition to the available K pools of soil (Sawarkar et al., 2015).

Table.1 Effect of long term application of fertilizers and manure on basic properties of soil

\begin{tabular}{|l|c|c|c|c|c|c|c|}
\hline \multirow{2}{*}{ Treatments } & Soil & Soil EC & \multicolumn{2}{|c|}{ Soil OC } & \multicolumn{2}{|c|}{$\mathbf{C a C O}_{\mathbf{3}}$} & \multicolumn{3}{|c|}{ Available Nutrients (kg ha-1) } \\
\hline & $\mathbf{p H}$ & $\mathbf{( d S m - 1 )}$ & \multicolumn{2}{|c|}{$\mathbf{( g ~ k g - 1 )}$} & $\mathbf{N}$ & $\mathbf{P}$ & $\mathbf{K}$ \\
\hline $50 \%$ NPK & 7.50 & 0.15 & 6.2 & 43.7 & 227 & 23.0 & 252 \\
\hline $100 \%$ NPK & 7.53 & 0.16 & 7.2 & 46.0 & 295 & 34.1 & 293 \\
\hline $150 \%$ NPK & 7.57 & 0.18 & 8.0 & 50.9 & 332 & 38.0 & 314 \\
\hline $100 \%$ NPK+HW & 7.54 & 0.16 & 7.2 & 46.4 & 295 & 32.3 & 288 \\
\hline $100 \%$ NPK+Zn & 7.55 & 0.17 & 7.2 & 44.4 & 294 & 32.5 & 284 \\
\hline $100 \%$ NP & 7.53 & 0.15 & 6.6 & 44.6 & 265 & 28.8 & 240 \\
\hline $100 \%$ N & 7.45 & 0.14 & 5.0 & 43.9 & 217 & 11.6 & 239 \\
\hline $100 \%$ NPK+FYM & 7.45 & 0.17 & 8.6 & 43.9 & 351 & 39.0 & 333 \\
\hline $100 \%$ NPK(-S) & 7.56 & 0.15 & 7.1 & 42.3 & 277 & 31.7 & 278 \\
\hline Control & 7.59 & 0.14 & 4.7 & 39.3 & 191 & 9.0 & 238 \\
\hline S Em \pm & $\mathbf{0 . 0 8}$ & $\mathbf{0 . 0 1}$ & $\mathbf{0 . 1 4}$ & $\mathbf{0 . 7 3}$ & $\mathbf{1 1 . 9 6}$ & $\mathbf{0 . 9 9}$ & $\mathbf{1 1 . 0 4}$ \\
\hline $\mathbf{C D}(\mathbf{p}=\mathbf{0 . 0 5})$ & $\mathbf{N S}$ & $\mathbf{N S}$ & $\mathbf{0 . 4 2}$ & $\mathbf{2 . 1 3}$ & $\mathbf{3 4 . 7 7}$ & $\mathbf{2 . 8 6}$ & $\mathbf{3 2 . 0 3}$ \\
\hline
\end{tabular}

Fig.1 Impact of different treatment on grain and straw yield of soybean

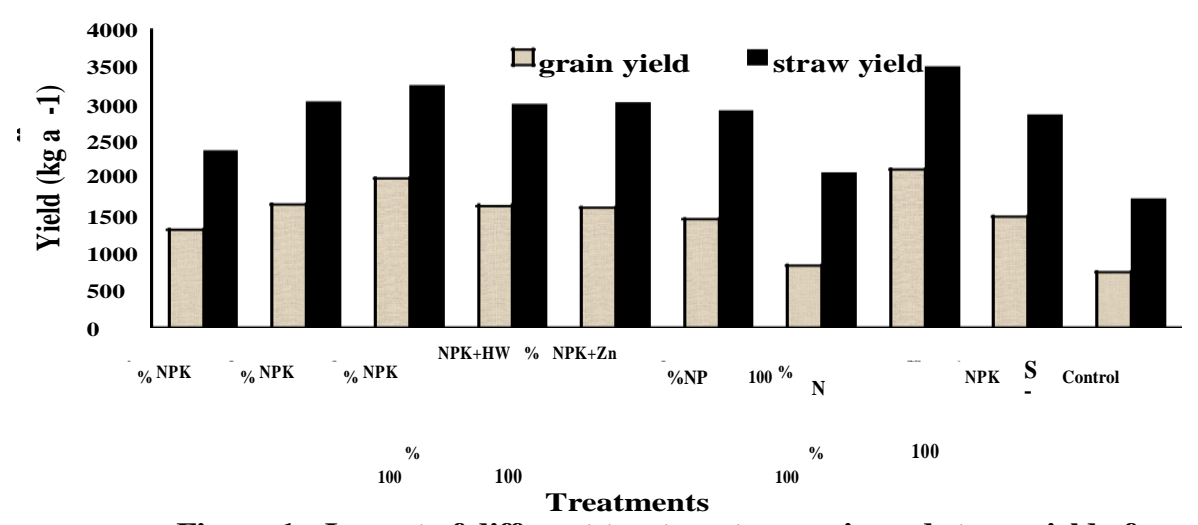

Figure 1 : Impact of different treatment on grain and straw yield of soybean 
Table.2 Effect of long term application of fertilizers and manure on nutrient uptake by soybean

\begin{tabular}{|c|c|c|c|c|c|c|c|c|c|c|c|}
\hline \multirow{3}{*}{ Treatments } & \multirow{3}{*}{ Grain } & \multirow{3}{*}{$\begin{array}{l}\text { Nitrogen } \\
\text { Straw }\end{array}$} & \multicolumn{9}{|c|}{ Nutrients uptake (kg ha-1) } \\
\hline & & & \multicolumn{4}{|c|}{ Phosphorous } & \multicolumn{5}{|c|}{ Potassium } \\
\hline & & & Total & $\underset{\mathbf{n}}{\text { Grai }}$ & Straw & $\begin{array}{r}\text { Tota } \\
\text { I }\end{array}$ & & Grain & & Straw & Total \\
\hline $50 \% \mathrm{NPK}$ & 67.9 & 53.5 & 121.4 & 3.57 & 3.48 & 7.05 & $\begin{array}{c}17.2 \\
8\end{array}$ & & 50.61 & & 67.89 \\
\hline $100 \%$ NPK & 100.9 & 91.4 & 192.3 & 6.00 & 5.34 & 11.34 & $\begin{array}{r}23.6 \\
2\end{array}$ & & 70.29 & & 93.91 \\
\hline $150 \%$ NPK & 125.3 & 108.0 & 233.3 & 7.72 & 5.98 & 13.69 & $\begin{array}{c}31.8 \\
1\end{array}$ & & 77.80 & & 109.61 \\
\hline $\begin{array}{l}100 \% \\
\text { NPK+HW }\end{array}$ & 95.3 & 88.4 & 183.7 & 5.58 & 4.92 & 10.50 & $\begin{array}{c}22.6 \\
4\end{array}$ & & 68.70 & & 91.33 \\
\hline $\begin{array}{l}100 \% \mathrm{NPK}+ \\
\mathrm{Zn}\end{array}$ & 96.7 & 89.9 & 186.6 & 5.79 & 5.27 & 11.07 & $\begin{array}{r}22 . \\
6\end{array}$ & & 69.41 & & 91.97 \\
\hline $100 \% \mathrm{NP}$ & 82.4 & 78.6 & 161.0 & 4.49 & 4.49 & 8.98 & $\begin{array}{c}17.6 \\
8\end{array}$ & & 56.05 & & 73.73 \\
\hline $100 \% \mathrm{~N}$ & 46.2 & 50.9 & 97.0 & 2.16 & 2.82 & 4.98 & $\begin{array}{c}10.1 \\
7\end{array}$ & & 39.58 & & 49.64 \\
\hline $\begin{array}{l}100 \% \\
\text { NPK+FYM }\end{array}$ & 135.8 & 120.7 & 256.5 & 8.39 & 6.54 & 14.93 & $\begin{array}{r}34 . \\
9\end{array}$ & & 87.79 & & 122.38 \\
\hline $100 \%$ NPK(-S) & 86.0 & 80.8 & 166.9 & 4.91 & 4.69 & 9.60 & $\begin{array}{r}20 . \\
0\end{array}$ & & 64.31 & & 84.81 \\
\hline Control & 37.5 & 35.1 & 72.6 & 1.85 & 2.43 & 4.28 & 8.8 & & 32.78 & & 41.62 \\
\hline S Em \pm & 4.71 & 4.65 & 5.68 & 0.32 & 0.32 & 0.44 & 1.0 & & 3.99 & & 4.36 \\
\hline \multirow[t]{2}{*}{$\mathrm{CD}(\mathrm{p}=\mathbf{0 . 0 5})$} & 13.66 & \multirow[t]{2}{*}{13.507} & 16.49 & \multirow[t]{2}{*}{0.925} & 0.93 & \multirow[t]{2}{*}{1.28} & \multirow{2}{*}{\multicolumn{2}{|c|}{3.07}} & \multirow{2}{*}{\multicolumn{2}{|c|}{11.59}} & \multirow[t]{2}{*}{12.67} \\
\hline & $\mathbf{0}$ & & 2 & & 3 & & & & & & \\
\hline
\end{tabular}

Fig.2 Impact of different treatment on nutrient uptake

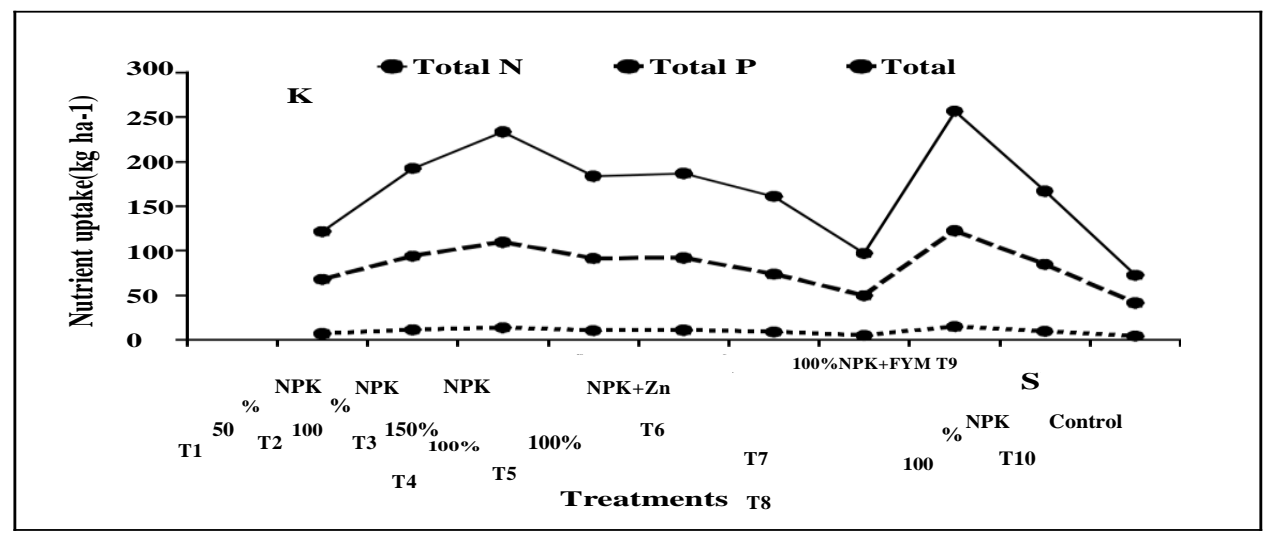

Soybean grain and Straw yield

Soybean seed yield indicated that the lowest seed yield was recorded in control $(737 \mathrm{~kg}$ ha-
1) followed by $100 \% \mathrm{~N}\left(825 \mathrm{~kg} \mathrm{ha}^{-1}\right)$. But when P fertilizer (100\% NP) was included in fertilizer schedule resulted in seed yield of $\left(1443 \mathrm{~kg} \mathrm{ha}^{-1}\right)$ while there was a further 
improvement noted in seed yield when $\mathrm{K}$ nutrient was included (100\% NPK) which accounted for about $1637 \mathrm{~kg}$ ha-1 over imbalanced NP application (Figure 1). On the contrary, there was a significantly decline in productivity of yield $\left(1480 \mathrm{~kg} \mathrm{ha}^{-1}\right)$ when sulphur nutrient was excluded (100\% NPK-S) dose which had resulted in comparatively lower seed over balanced fertilizer addition (1637 kg ha-1). It has also been observed that successive addition of fertilizer progressively increased the seed yield of crop (Dwivedi and Dwivedi, 2015). In this regard, proportionately significant lower yield was associated with $50 \% \mathrm{NPK}$ as compare to balance application of $100 \%$ NPK. However, the significant higher yield was obtained with $150 \%$ application of NPK. The maximum seed yield was noticed with integrated application of $100 \%$ NPK along with FYM (2106 kg ha-1) over balance application of $100 \%$ NPK in soybean. Application of recommended optimal dose (100\% NPK) resulted in productivity of seed yield for 1637 $\mathrm{kg}$ ha-1 but exclusion of sulphur (i.e. $100 \%$ NPK-S) dose had resulted in lower seed yield (1480 kg ha-1) amounted to decline yield of soybean. Similar results have also been observed by Sawarkar et al., (2010), Dwivedi et al., (2016) and Gupta et al., (2019).

\section{Nutrient Uptake by Soybean}

The data portioning to nutrient uptake by soybean was presented in table 2 and illustrated in Figure 2 and revealed that the nutrient uptake differs significantly with different treatment combinations. In seed, maximum uptake of $\mathrm{N}, \mathrm{P}$ and $\mathrm{K}$ was recorded under treatment receiving $100 \% \mathrm{NPK}+5 \mathrm{t}$ FYM ha ${ }^{-1}$ was $135.80 \mathrm{~kg} \mathrm{ha}^{-1}, 8.39 \mathrm{~kg}$ ha1and $34.59 \mathrm{~kg}$ ha-1 respectively. Applied FYM with $100 \%$ NPK helped to increase the $\mathrm{N}$ uptake by soybean seed as compared to the application of $100 \%$ NPK (100.91 kg ha-1) while, further addition of P (100\% NP) was significantly raised the uptake. Similar findings were reported by Raghuwanshi et al., (2016). All the treatments were found significantly higher $\mathrm{K}$ uptake by soybean seed over control except $100 \% \mathrm{~N}$ alone. In straw the highest phosphorus uptake (6.54 kg ha-1) was recorded with treatment receiving $100 \%$ NPK + 5 t FYM ha-1 followed by $150 \%$ NPK (5.98 kg ha-1). The successive addition of fertilizer had resulted in higher content and uptake by seed and straw of soybean. This could be due to successive addition of $\mathrm{P}$ through fertilizer which had resulted in proportionately, higher availability in the soil for its subsequent uptake and utilization by plants. Hence, the lowest content of $\mathrm{P}$ coincided with control and $100 \% \mathrm{~N}$ alone plots. Similar result was reported by Sharma and Vikas (2007). There was a progressive increase in $\mathrm{K}$ content and uptake with successive additions of NPK fertilizer over sub optimal, imbalance or without fertilizer addition, which could obviously be a result of successive addition of $\mathrm{K}$ through higher fertilizer doses (Dwivedi et al., 2007).

It was concluded that maximum number of nodules was recorded with optimal + FYM followed by super optimal dose (150\% NPK) and minimum in control. Nodulation (both nodule number and oven dry weight) increased in all the treatments expect $100 \% \mathrm{~N}$ dose where it decreased significantly over control. It was found maximum in $100 \%$ NPK dose + FYM followed by $150 \%$ NPK dose. The $\mathrm{N}_{2}$ fixation of soybean was significantly increased with increase fertilizer application rate. Maximum nitrogen fixation and seed yield of soybean was found in treatment receiving 100\% NPK + FYM (197 kg ha ${ }^{-1}$, $\left.2106 \mathrm{~kg} \mathrm{ha}^{-1}\right)$ and minimum in control $(66 \mathrm{~kg}$ ha-1, $737 \mathrm{~kg} \mathrm{ha}^{-1}$ ) respectively.

It is concluded that under continuous cropping with soybean and wheat in sequence over fourty six years, conjoint use of organic 
manure along with $100 \%$ NPK not only sustained the higher yield of both soybean and wheat, but also improved the soil fertility. The findings indicated that balance use of fertilizers alone or in combination with organic manure resulted in significant buildup of organic carbon and available N, P and $\mathrm{S}$. A declining trend of available $\mathrm{K}$ from its initial status was noticed as a result of continuous cropping, which indicated considerable soil mining of available $\mathrm{K}$. Incorporation of fertilizers and manure in swell-shrink soils improved the bulk density and hydraulic conductivity. Further, nutrient balance of soil implied build-up of phosphorous under soybean-wheat cropping sequence, which needs refinement of $\mathrm{P}$ level recommendations.

\section{References}

A.O.A.C., 1995. Association of Official Agriculture Chemists. Official Methods of analysis 12th Ed. Washington, D.C. USA.

Bhargava, B.S. and Raghupathi, H.B., 1984. Analysis of plant materials for macro and micronutrient, pp. 49-82. In: HLS Tandon (Ed.). Methods of analysis of soils, plants, waters and fertilizers. Fertilizer development and consultation organization, New Delhi.

Divya, M., Jagadeesh, B.R., Srinivasa, D.K. and Yogesh, G.S., 2016. Effect of long term soil fertilizer application on forms and distribution of potassium in soil under rice- cowpea cropping system. Asian Journal Soil Sci. 11 (1): 9-19.

Dwivedi, A.K. and Dwivedi, B.S., 2015. Impact of long term fertilizer management for sustainable soil health and crop productivity: Issues and challenges. JNKVV Res. Journal 49 (3): 387-397.

Dwivedi, A.K., Singh, M., Kauraw, D.L.,
Wanjari, R.H. and Chauhan, S.S., 2007. Research bulletin on impact of fertilizer and manure use for three decades on crop productivity and sustainability and soil quality under Soybean-Wheat system on a Vertisol in Central India. IISS (ICAR), Bhopal pp. 224-235.

Dwivedi, B.S., Rawat, A.K., Dixit, B.K. and Thakur, R.K., 2016. Effect of inputs integration on yield, uptake and economics of Kodo Millet (Paspalum scrobiculatum L.). Economic Affairs, 61(3): 519-524.

Gupta, A., Dwivedi, A.K., Nagwanshi. A., Dwivedi, B.S. and Vishwakarma, A.K., 2019. Impact of Long Term application of inorganic fertilizer and farmyard manure on Productivity of Soybean in Vertisol. Bull. Env. Pharmacol. Life Sci., Vol 8: 116-122. ISSN 2277-1808.

Ibrahim, S.A. and Kandil, H., 2007. Growth, yield and chemical constituents of Soybean (Glycine max L.) plants as affected by plant spacing under different irrigation intervals. Research Journal of Agriculture and Biological Science 3(6): 657-663.

Keyser, H.H. and Li, F., 1992. Potential for increasing biological nitrogen fixation in soybean. Plant Soil 141: 119-135.

Khamparia, N.K., Thakur, R.K. and Sawarkar, S.D., 2018. Effect of Continuous Use of Inorganic Fertilizers and Organic Manure on Crop Productivity, Soil Fertility and Sustainability of Soybean-Wheat Cropping System in a Vertisol. Journal of Soils and Crops, 28(1): 1925. Muhr, G.R., Datta, N.P., Subaramany, H.S., Leley, V.K. and Dunahue, R.L., 1965. Soil testing. India Asian Press. New Delhi.

Mundhe, S., Dhawan, A.S. and Syed, I., 2018. Long-Term Effect of Organic Manure 
and Fertilizers on Soil Organic Carbon Pools Under Soybean-Safflower Cropping System in Vertisol. International Journal of Agriculture Sciences, Volume 10, Issue 10, pp.6137-6140.

Nagwanshi, A., Dwivedi, A.K., Dwivedi, B.S. and Anupama, K., 2018. Effect of long term application of fertilizer and manure on soil properties of a Vertisol in soybean-wheat cropping sequence. International Journal of Chemical Studies 6(3):2946-2949.

Olsen, S.R., Cole, C.V., Watanabe, F.S. and Dean, L.A., 1954. Estimation of available phosphorus in soil by extraction with sodium bicarbonate $\left(\mathrm{NaHCO}_{3}\right)$. U.S.D.A. Cir., 939: 1-19.

Patel, G., Dwivedi, B.S., Dwivedi, A.K., Thakur, R.K. and Singh, M., 2018. Long-term effect of nutrient management on soil biochemical properties in a Vertisol under soybean - wheat cropping sequence. Journal of the Indian Society of Soil Science, 66(2): 215-221.

Piper, C.S., 1950. Soil and plant Analysis. Inter Sci. Publi., Inc., New York. Puri, A.N., 1930. A new method of estimating total carbonates in soils. Imperial Agricultural Research Institute Pusa Bulletin 7: 206-207.

Raghuwanshi, C., Khamparia, N.K., Thakur, R., Sahare, S.K., Sharma, V. and Dwivedi, B.S., 2016. Impact of long term application of inorganic fertilizers and organic manure on yield attribute characters, yield of soybean and soil fertility in a Vertisol. Eco. Env. \& Cons. 22(2): 745-753.

Sawarkar S.D., Singh, M., Khamparia, N.K., Wanjari, R.H. and Thakur, R.K., 2015. Research Bulletin on Long Term Impact of Fertilizer and Manure on Soil Quality, Crop Productivity and Sustainability under Soybean-Wheat
System in Vertisol. AICRP on LTFE, ICAR - Indian Institute of Soil Science, Bhopal, pp 1-63.

Sawarkar, S.D., Khamparia, N.K., Thakur, R., Dewda, M.S. and Singh, M., 2013. Effect of long term application of inorganic fertilizers and organic manure on yield, Potassium uptake and profile distribution of potassium fractions in vertisol under soybeanwheat cropping system. J.Indian Soc. Soil Sci,. 61(2) : 94-98.

Sawarkar, S.D., Thakur, R. and Khamparia, R.S., 2010. Impact of long term continuous use of inorganic and organic nutrients on micronutrients uptake by soybean in Vertisol. Journal of Soils and Crops. 20 (2): 207-210.

Sharma, H.K. and Srilatha, M., 2015. Influence of long term use of fertilizers and manures on available nutrient status and inorganic "Phosphorous" fractions in soil under continuous rice-rice cropping system. International Journal of Advanced Research 3(6): 960-964.

Sharma, S.K., Singh, V.P., Chouhan, N. and Sawarkar, R., 2016. Effect of LongTerm Fertility Management Practices on Soil, Crop Quality and Productivity of Soybean Grown in Vertisols of Western Madhya Pradesh. International Journal of Agriculture Sciences, ISSN: 0975-3710 \& E-ISSN: 0975-9107, Volume 8, Issue 60, pp.3374-3377.

Sharma, V. and Vikas, A., 2007. Effect of phosphorous and zinc application on yield and uptake of $\mathrm{P}$ and $\mathrm{Zn}$ by chickpea under rainfed conditions. Journal of food legumes, 20 (1): 4951.

Shirale, S.T., Kide, D.S. and Meshram, N.A., 2014. Long-term effect of organic manuring and inorganic fertilizers for enhancing yield and soil properties 
under soybean (Glycine max L.)safflower (Carthamus tinctorius L.) cropping sequence in Vertisol. Asian J. Soil Sci., 9(1): 130-136.

Singh, M., Wanjari, R.H., Dwivedi, A. and Dalal, R., 2012. Yield Response to Applied Nutrients and Estimates of $\mathrm{N}_{2}$ Fixation in 33 Year Old SoybeanWheat Experiment on a Vertisol. Expl.Agri,.48 (3):311-325.

Subbiah, B.V. and Asija, E.C., 1956. A rapid procedure for estimation of available nitrogen in soil. Curr. Sci., $25: 259$ 260.

Thakur, R.K. and Sawarkar, S.D., 2009. Influence of long term continuous application of nutrients and spatial distribution of sulphur on soybeanwheat cropping sequence. Journal of Soils and Crops 19, 225 - 228.

Thakur, R.K., Sawarkar, S.D., Vaishya, U.K. and Singh, 2011. Impact of continuous use of inorganic fertilizers and organic manure on soil properties and productivity under soybean-wheat intensive cropping of a Vertisol. $J$. Indian Soc. Soil Sci. 59 (1):74-81.

Walkley, A. and Black, 1.A. 1934. Estimation of soil organic carbon by the chromic acid titration method. Soil Sci., 47 : 29-38.

\section{How to cite this article:}

Jalendra Bairwa1, B. S. Dwivedi, A. K. Dwivedi, R. K. Thakur and Patidar, N. 2020. Impact of Long Term Fertilization on Soil Properties and Soybean Productivity in a Vertisol. Int.J.Curr.Microbiol.App.Sci. 9(09): 527-536. doi: https://doi.org/10.20546/ijcmas.2020.909.067 